\title{
The Historical and Archeological Significance Dera Ghazi Khan District through Ages
}

\author{
Sohail Akhtar* \\ Lecturer in History, Ghazi University, Pakistan \\ *Corresponding author: Sohail Akhtar, Lecturer in History, Ghazi University, Pakistan
}

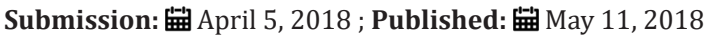

\begin{abstract}
Dera Ghazi Khan is one of the most important and historic city of Pakistan. With socio-cultural importance it has a valuable status and importance due its Geo-strategic position in the region. Dera Ghazi Khan remained and important part of Indus civilization and was a centre of various ancient nations as Dravidians, Arians and many others nations. This research Paper is a short review about the Geo-Historic and Archeological importance of Dera Ghazi Khan District.
\end{abstract}

Keywords: History; Anthropology; Archaeology; Dera ghazi khan

\section{Introduction}

Dera Ghazi Khan is a southern most district of Punjab in Pakistan. It is an old and historical city of Pakistan and is one of the most populous cities in Southern Punjab. Dera Ghazi Khan declared as a division in 1982. Dera Ghazi Khan city is the headquarters of Division, which consists of the Dera Ghazi Khan, Rajanpur, Muzaffargarh and Layyah districts [1]. The city was founded in 1484 on the western bank of the Indus River and named after Nawab Ghazi Khan Mirani, son of Nawab Haji Khan Mirani, a Balochi chief, who had declared independence from the Langah Dynasty's Sultans of Multan. Together with two other Deras i.e. settlements, Dera Ismail Khan and Dera Fateh Khan, it gave its name to Derajat. Derajat eventually came into the possession of the British after the Sikh War in 1849 and was divided into two districts: Dera Ghazi Khan and Dera Ismail Khan. The population was 1,643,118 as enumerated in March 1998 with an increase of 74\% since March 1981 when it was 943665. It had grown at an average annual rate of $3.3 \%$ since the last census reported its. The growth rate was higher in the decade prior to the eighties when Dera Ghazi Khan grew annually by $3.8 \%$ of population [2]. The density ratio was 138 persons per square kilometre as against 79 persons observed in 1981 . The urban population was 228,839 or $13.9 \%$ of the total population of the district. There is a town committee and a municipal committee in the district. While 826 Mauzas and 91 union Councils are also part of the district.

According to Punjab Development Statistics 2008, total population of Dera Ghazi Khan District is 2,128 thousands persons out of which 1,107 thousands are males and 1,021 thousands are females [3]. Density of population in the district is 178 persons per square Kilometre. A horrible flood destroyed the old city in 1909 and the new town is located in west around 10 miles (16km) away from the old town [4].

The district of Dera Ghazi Khan is bounded on the north by Dera Ismail Khan District of KPK and its adjoining Tribal area. On the west by Musa Khel and Barkhan district of Balochistan province. On the south by Rajanpur district and on east Muzaffargarh and layyah separating the latter two districts by river Indus. Dera Ghazi Khan is an important region of Pakistan which historically played a significant role during the colonial rule in Subcontinent [5]. The region has a sound and marvellous history from the ancient time to modern era. People of various generations and castes settled and lived in this part of the world. Therefore, a long history going back at least to the times of beginning of the Early Harappan Civilization in the fifth century B.C .

Before the beginning of the Harappan Civilization this area must have been in habited by some people and after the settlement of the Aryans many more peoples came here from different directions and settled here. But unfortunately, the early phase of history of this region prior to 15 th century has not been documented adequately and authoritatively [6]. We hear and read in local history about Acheamenian princesses, Alexander's romance, and stories of Dillau Rai and Raja Rasalu. But none of these stories rises above the status of folklore and folk tale. History cannot be reconstructed with the help of assumptions. The Dera Ghazi Khan district assumes geostrategic significance owing to its geographical location. It occupies 
the traditional routes of invaders as well as traders. Its proximity to Balochistan and N.W.F.P places it at the most sensitive geo-strategic position [7-9]. Being the part of Punjab, it was the first halting place of all invaders from north and north western side and acted as a natural citadel of the gigantic valley.

After the establishment of Afghan power in the eighteenth century, the town of Dera Ghazi Khan increased its commercial importance due to its place in Kandhar and Kabul trade route and due to the increase presence of both Afghan and particularly Shikarpur Hindu traders in the town. Alexander Burns, as a special envoy of the Governor General to Maharaja Ranjeet Singh under took a journey form Sind to Punjab through river Indus in 1830s. He noted that the town had once been known as one of the gates of Khurasan. That Hindu capital found its way into agricultural production on canal land. He also suggested the importance of Indigo, a commercial crop that also played an important role in the town's exports, in which traders usually had a high stake.

With historic importance strategic location of this region reveals its ineffectiveness as an area of operation for invaders who descended through several passes in the Hindu Kush Mountains on the North. Actually, it always lay far away from the recognized marching routes of the invading armies. Equally, and for the same reason [10], this area does not promise a bright prospect of a settled life of human habitation. It is a region of tribal chivalry and spirit of traditionalism a strong complex of individuality an identity-more or less a causality of legend of self glorification. However still, the Indus River-the principal water course, proved to be the route of trade to from time immemorial. Geographical contiguity of the neigh boring provinces NWFP, Sind, Baluchistan and the deserts of Cholistan and Rajasthan helped to keep its door open to influences of cultural invasions from all sides.

The archaeological worth and wealth of this region still remains and recent archaeological explorations of the region by Pakistani archaeologists, though still in their infancy, are gradually diluting the thick fog of ignorance that engulfs the minds of our scholars. Situated as this region is on some ancient trace routes between Afghanistan and beyond, on the one hand, and whole of the subcontinent on the other hand, as well as its location beside the Indus River the only navigable river of Pakistan flowing between the Arabian Sea and the Himalayan mountains, the area was destined to play significant role in ancient times in the cultural interaction between Central Asia and Northern India.

Even during the middle if the 19th century, the cities of Dera Ghazi Khan for going to Kabul, Kandhar and Ghazni in Afghanistan by way of Lakki, and Chaudhwan, Akra (Bannu) and Tank, Dera Ismail Khan, Dhadhar (near Bolan Pass), Shikarpur, etc. In the opposite direction-the mainland India, these routes reached various distant stations in Northern and Central India such as Mombai, Madras and Delhi, via Khushab, Multan, Sukkaur, Arana, Uch Sharif, etc. The early Hindu writers mistook the Indus River near Dera Ghazi Khan to be a Sagar i.e. sea and named it as Sind Sagar [11]. A route, through Sakhi Sarwar, a suburban village of
Dera Ghazi Khan and famous shrine, was used by the trade carvans to reach Kandhar and Kabul. In the reign of Akbar, the great, the courtiers usually used this route for reaching Multan from Kandhar and mangoes were conveyed to Kandhar from Multan in six days for commercial purposes.

Khyber Pass connects the Peshawar valley with Kabul in the north of the mountain, Tochi and Gomal passes connect the plains of the Indus with Ghazni and South Afghanistan. Similarly, the Mullah, the Bolan and the Khojak passes connect the plains of Sind and Dera Ghazi Khan with the plateaus of Kalat and Kandhar. The British realized the full potential of this district when they annexed the Derajat in 1849 into their fold. In the wake of The Great Game [12], the British and the Russians started showing interests in Afghanistan since the beginning of 19th century. The "Great Game", as it came to be called later, started when Persia, with the Russian help, attempted to take over Herat during Dost Mohammad's rule.

Later on, in the 4th century BC. Alexander the Great, during his passage back home, voyaged from Jhelum to the Indus Delta and on the way; he laid the foundation of a Greek city at the confluence of the five rivers i.e. somewhere between Mithan Kot and Panjn and possibly Uch Sharif of today. Alexander's passage through Southern Punjab was full of troubles as local people offered him stiff resistance. The area occupied by Dera Ghazi Khan District has a large number of passes in the Suleiman Range through which our area is connected with countries that lay west of the Suleiman Range. Different scholars have mentioned different number of these passes-the number varies from 32 to 92 [13]. But, the passes of Sakhi Sarwar and Sanghar seem to have been the most important ones. From time immemorial till the middle of the 20th century, Pawindas have been using the so-called Qafila Route for their migratory roaming between Afghanistan and Pakistan and even beyond into the heart of India. During historic period several kings and princes used one or the other of these routes for their journeys to and from Baluchistan, Afghanistan and Iran. For example Babur is believed to have used Sakhi Sarwar and Boree routes in 1505 and Prince Dara Shikoh sneaked himself out of Aurangzeb's hands through Sanghar Pass.

Nutkani has also mentioned about an Arabic inscription of the period of Altutmush from a near Harrand Besides, a recent survey has locates some 18 sites and monuments that can be dated between 15th to 18th centuries. Most important among these are the Fort of Harrand, some tombs at Meehan Kot, Taunsa Sharif and Pir Adil. And that is all we know about the archaeology and archaeological remains in this largest Division of the Punjab.

Afghanistan was significant for Russia during this period for the following three reasons: First, the security of Russia's trade and the significance of Afghanistan in meeting those. Right from the period of Peter the Great in the eighteenth century [2], Russia had been looking for a warm water port to make their trades secure. An access through Afghanistan would always be in the interest of Russia 's trade relations with other countries. Secondly, Czarist Russia shared ethnic relations with Afghanistan, and it would be 
in the interest of Russia to see Afghanistan remaining peaceful. Afghanistan, either under the direct or indirect control of forces that are not friendly to Russia, could create trouble among Russian subjects.

Thirdly, losing Afghanistan to other powers would undermine the imperialist objectives of Czarist Russia in Afghanistan. The British interests in Afghanistan were based on two factors. Firstly, they feared that advancement of Russian interests in Afghanistan would ultimately result in their monopoly being challenged in India because of the ancient historical, religious and cultural linkages between Central Asia and South Asia. This link ages goes all the way back to the period of the Indus Valley Civilization. Successive Indian Rulers from Chandragupta Maurya onwards pursued a 'forward policy' towards Central Asia. In turn, successive Central Asian leaders and people penetrated South Asia during the latter's long period of internal weakness. Secondly, the British believed that access to Afghanistan would result in Russia looking for a warm water port in this region, which would increase the economic and colonial prospects of Russia. Consequently, the British colonial rulers were convinced that a friendly power and an intimate connection in Afghanistan, a peaceful alliance with Lahore and an established influence in Sind and Balochistan, were the object for which some hazard might well be run.

The British raised a special force named as 'Indus Army' with the tacit approval of Ranjit Sing to remove the Ruler of Afghanistan, Dost Muhammad Khan, Who had refused to surrender Peshawar to the Sikhs. The British with the help of Ranjit Sing wanted to install Shah Shuja who had agreed to align the destiny of Afghanistan with Indian sub-continent rather than with Central Asia. . However, when the time came for the Indus Army to attack Afghanistan, Ranjit Sing not only withdrew his pledge to support this mission but also refuse to let Lt. General Sir J. Keane, Commandant of the Indus Army, to march through his territory.

General Kaeane has to find an alternative route, almost threefold longer through Sind and Balochistan. The expedition proved disastrous and the British had to retreat. In the aftermath of this humiliating defeat of the British in the first Afghan war in 1842 , the importance of Sind and Balochistan along with the Indus basin plains of Derajat increased even more [14]. The logistic and strategic importance of these areas, especially the coastal areas of Blochistan attracted the British for their west-ward expansion. They wanted to capture a suitable port like Jiwany, which was on few days cruise from Bombay. The British had already acquired Karachi port facilities in 1820's. During this engagement, the political and administrative vulnerability of local rulers were also exposed to the British which they used in their advantage in subsequent years.

In this regards, the British raised a special force named as 'Indus Army' with the tacit approval of Ranjit Sing to remove the Ruler of Afghanistan [15], Dost Muhammad Khan, Who had refused to surrender Peshawar to the Sikhs. The British with the help of Ranjit Sing wanted to install Shah Shuja who had agreed to align the destiny of Afghanistan with Indian sub-continent rather than with Central Asia.

Even in the recent time the corridor of china has link with Dera Ghazi Khan to Gowadar port. "The project will help save time, cost and freight charges, as it is the shortest route between China, the Middle East and European countries through Gowadar port. PakChina Link Road will cross through Dera Ghazi Khan .The prime minister said a Chinese delegation would arrive in Islamabad Monday to review the proposed economic corridor project. He added that special economic zones would be established in Dera Ghazi Khan and along the economic corridor, and that Chinese companies have shown willingness to set up industries in the zones. Gowadar port has the potential to become a free port.

\section{Conclusion}

The above mention discussion highlights the geo-strategic importance of the region which thought a poor and backward area in 21st century. Poor as this region may look for its archaeological heritage, but it definitely has share in the architectural heritage of the entire Southern Punjab. Since it has always been a land of saints, Nawab, Sardars/Tumandars, the region has quite a large number of shrines and tombs of eminent personalities. They play a role in the region.

\section{References}

1. District Census Report (1998). p. 3.

2. Lala Hutto, Ram Gul Bahar (1981) Quetta, Pakistan, p. 11.

3. District Census Report (1998) District Dera Ghazi Khan, Govt. of Pakistan, Islamabad

4. Population Census organization (1999) Statistics Division, Govt. of Pakistan, Islamabad.

5. Khan Legari, Abdul Qadir, Tarikh DG khan (1986) D.G.Khan: Indus Publication Multan. 1: 8.

6. District Gazetteer of Dera Ghazi Khan. p. 13.

7. Budha Parkash (1976) Political and social movements in ancient Punjab, Lahore, Punjab, p. 1.

8. Burns A (1837) On the Trades of the upper Indus of Derajat, Vol. no. 94.

9. Tawareekh-e-Dera Ghazi Khan. p. 6.

10. Major Henery George Raverty (1976) Notes on Afghanistan and Baluchistan, Sang-e-Meel Publications, Lahore, India.

11. The farward Policy. p. 9.

12. District,Gazetteer. p. 13.

13. Ghulam Ali \& Nutkani (1986) Muraqa Dera Ghazi Khan. Multan, p. 12.

14. Javed Haider Syed (2007) British advent in Balochistan in Pakistan Journal of history and culture 28(2):59.

15. Embree AT (1979) Pakitan Western Borderlands, pp. 30-31. 
Creative Commons Attribution 4.0 International License

For possible submissions Click Here

Submit Article

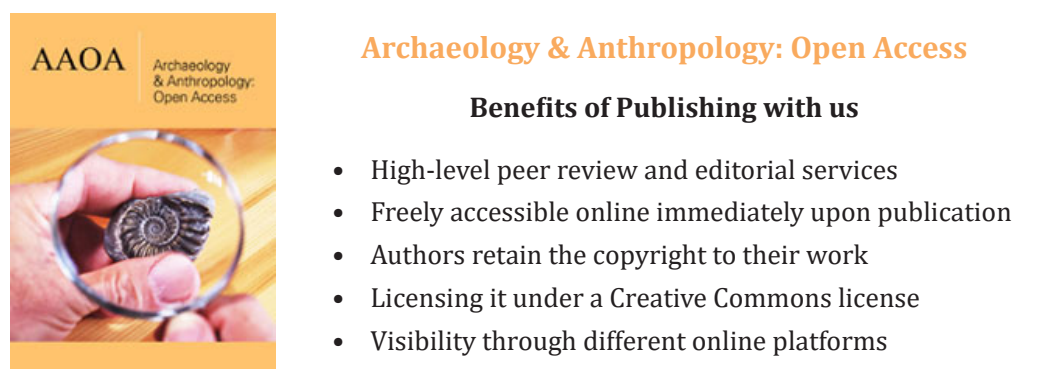

